GABA-GABA: Jurnal Pengabdian Masyarakat dalam bidang Pendidikan Bahasa dan Seni Vol. 3 No. 1, Desember 2021, Hal. 110-114

e-ISSN: 2797-8494

\title{
PELATIHAN PENINGKATAN KETERAMPILAN MENULIS DENGAN MENGGUNAKAN ASSOZIOGRAMM BAGI GURU BAHASA JERMAN
}

\author{
${ }^{1}$ Program Studi, Pendidikan Bahasa Jerman \\ FKIP UNPATTI \\ email: akiharywilma@gmail.com \\ ${ }^{2}$ Program Studi, Pendidikan Bahasa Jerman \\ FKIP UNPATTI \\ email: treisapituley@yahoo.com \\ ${ }^{3}$ Program Studi, Pendidikan Bahasa Jerman \\ FKIP UNPATTI \\ email: c.lestuny14@gmail.com \\ ${ }^{4}$ Program Studi, Pendidikan Bahasa Jerman \\ FKIP UNPATTI \\ email: derkoenig@yahoo.com
}

Wilma Akihary ${ }^{*)}$, Patresya S. Apituley ${ }^{2)}$ Carolina Lestuny ${ }^{3)}$ Piet Soumokil ${ }^{3)}$

\begin{abstract}
Abstrak
Pelatihan yang berbasis blended learning ini diselenggarakan oleh Program Studi Pendidikan Bahasa Jerman bagi guru bahasa Jerman bertujuan untuk meningkatkan kemampuan menulis guru bahasa Jerman pada level B1 dengan menggunakan teknik Assoziogramm. Dalam pelatihan ini guru diberikan pengenalan tentang model tes menulis bahasa Jerman level B1 yang sesuai Gemeinsamer europäischen Referenzrahmen (GER), dan juga penggunaan teknik Assoziogramm untuk mengembangkan keterampilan menulis baik secara kelompok maupun individu. Sebanyak 18 guru bahasa Jerman yang telah memiliki ijasah level A1-B1 turut serta dalam pelatihan ini. Metode yang digunakan adalah metode eklektik. Hasil akhir pengabdian ini adalah adanya output dalam bentuk hasil kerja kelompok berupa Assoziogramm dan juga karangan tentang Umweltschutz serta hasil kerja pribadi berupa Assoziogramm dan karangan tentang Online-Lernen.
\end{abstract}

Kata Kunci: Assoziogramm, keterampilan menulis

\section{Abstract}

Training which is based on blended learning organized by the German Language Education Study Program for German language teachers aims to improve the writing ability of German teachers at level B1 by using the Assoziogramm technique. In this training, the teacher is given an introduction to the German language writing test model level B1 which is suitable for the Gemeinsamer europäischen Referenzrahmen (GER), and also the use of the Assoziogramm technique to develop writing skills both in groups and individually. A total of 18 German teachers who already have A1-B1 level certificates participated in this training. The method used is the eclectic method. The final result of this training is the output of group work in the form of an Assoziogramm and also an essay on Umweltschutz as well as personal work in the form of Assoziogramm and essays about Online-Lernen.

Keywords: Assoziogramm, writing skills 


\section{PENDAHULUAN}

Seorang guru bahasa Jerman dituntut untuk memiliki kemampuan berbahasa Jerman yang baik. Itu berarti guru tersebut harus menguasai empat keterampilan berbahasa yaitu keterampilan menyimak (Hörverstehen), keterampilan berbicara (Sprechfertigkeit), keterampilan membaca (Leseverstehen), dan keterampilan menulis (Schreibfertigkeit). Keempat keterampilan tersebut memampukan guru tersebut untuk mentransfer ilmunya dengan baik.

Keterampilan menulis merupakan salah satu keterampilan produktif. Keterampilan ini memiliki tingkatan/level tertentu. Dalam penguasaan bahasa Jerman, terdapat 6 tingkatan, yakni A1, A2, B1, B2, C1 dan C2. Tiap level itu memiliki tingkat kesulitan yang berbeda. Berdasarkan kerangka acuan Uni Eropa untuk bahasa (GER= Gemeinsaer europäischer Referenzrahmen für Sprachen) pada level B1 Schreiben (menulis), seorang pebelajar bahasa dapat menulis secara sederhana dan koheren tentang tema yang menarik minat pebelajar tersebut. Dia dapat pula menulis surat pribadi dan menceritakan pengalaman dan kesan-kesan.

Berdasarkan hasil wawancara dengan guru diketahui bahwa 94\% guru mengalami kesulitan dalam menulis. Hal ini menyebabkan mereka mendapat nilai menulis rata-rata bahkan ada yang di bawah standart. Diakui bahwa mereka tidak/kurang terlatih dalam menulis karena tidak banyak tuntuan untuk menulis bahasa Jerman dalam pekerjaan mereka. Mereka lebih sering membahas bacaan dan struktur dan juga memeriksa tulisan siswa, tapi mereka sendiri secara pribadi tidak berlatih menulis untuk mencapai tingkatan tertentu. Hal ini menyulitkan mereka saat mereka harus melalui ujian keterampilan memenulis pada level tertentu.

Pepatah bahasa Jerman Übung macht den Meister 'latihan membuat orang menjadi ahli' dapat diterapkan dalam meningkatkan kemampuan menulis. Selain itu, dibutuhkan pula teknik tertentu yang dapat memancing guru-guru dalam pelatihan ini untuk mengemukakan ide-ide, mengelompokkan ide-ide tersebut dan kemudian menuangkannya dalam bentuk tulisan. Terdapat beberapa teknik yang dapat digunakan untuk melatih keterampilan menulis. Salah satu teknik yang atraktif untuk melakukan hal tersebut adalah Assoziogramm.

Teknik Assoziogramm ini pertama kali digunakan oleh Gabriele L Rico, seorang dosen seni di Universitas San Jose. Ia menggunakan metode ini karena mahasiswa seni merasa kesulitan dalam hal menuangkan ide, perasaannya untuk menulis (Hernowo, 2005: 141). Berdasarkan hasil penerapan metode ini terlihat bahwa mahasiswa seni mampu berpikir lebih kreatif dalam menulis. Sementara itu, menurut Wacker (1996: 25), “mit Assoziogramm sammelt man Assoziationen, die durch ein Wort ausgelöst werden. Dem Wort, Satz, usw werden Wörter zugeordnet, die dann in Bezug zueinander treten (Bezügsbundel) und ein bestimmtes Thema ergeben “. Artinya, Assoziogramm membantu mengumpulkan dan menemukan kata yang relevan dari suatu tema. Dalam hal ini Assoziogramm juga membantu untuk menghubungkan dan mengembangkan gagasan serta meningkatkan dan melatih logika dan kreatifitas

Berdasarkan hasil wawancara tersebut di atas, Program Studi Pendidikan Bahasa Jerman berinisiatif membuat pelatihan untuk meningkatkan keterampilan menulis guru bahasa Jerman dengan menggunakan teknik Assoziogrammm mengingat teknik ini yang dapat memancing guru mengemukakan ide-ide, mengelompokkan ide-ide tersebut dan kemudian menuangkannya dalam bentuk tulisan. Diharapkan bahwa pelatihan ini dapat memberikan kontribusi bagi guru bahasa Jerman dalam mengikuti tes bahasa Jerman level B1. 


\section{METODE PELAKSANAAN}

Bentuk kegiatan Pengabdian Kepada Masyarakat yang dilakukan berupa pelatihan bagi 18 guru bahasa Jerman. Pelatihan ini berbentuk blended learning dengan jumlah waktu pembelajaran 8 JP (1 JP sama dengan @ 45 menit). Tatap muka dilaksanakan pada tanggal 31 Agustus di Aula A Kompleks PGSD, Jl. Dr. Siwabessy sebanyak 4 JP (1 JP = 45 menit). Selanjutnya secara online, peserta pelatihan mengerjakan tugas yang diberikan sebanyak 4 JP untuk mengembangkan tulisannya secara mandiri dengan menggunakan metode Assoziogrammm.

Dalam pelatihan ini terdapat beberapa langkah yang dilakukan, yakni:

a. Tim PKM memperkenalkan tujuan pelatihan, pengenalan model tes menulis level bahasa Jerman B1 berbasis Gemeinsamer europäischen Referenzrahmen (GER), pengenalan dan juga penggunaan teknik Assoziogramm untuk mengembangkan keterampilan menulis.
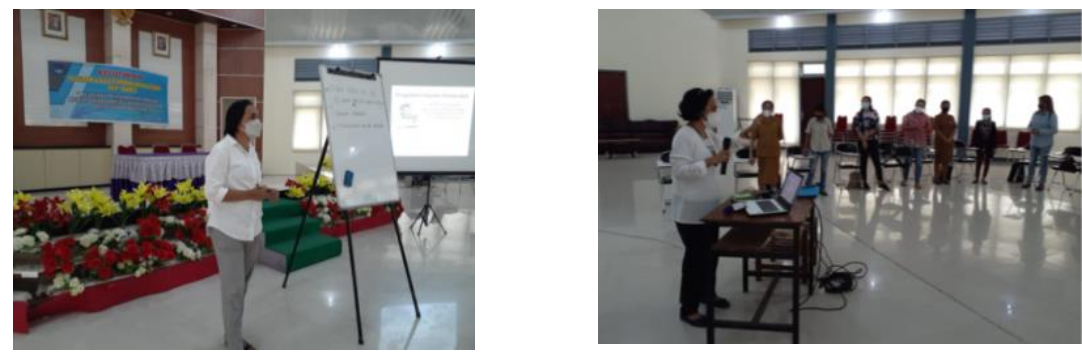

b. Peserta diberikan karton manila dan spidol untuk mengerjakan Assoziogramm dan menulis karangan berdasarkan Assoziogramm yang telah dibuat dalam kelompok. Setelah waktu yang telah ditentukan selesai, masing - masing kelompok mempresentasikan hasil kerja yang telah dibuat. Selanjutnya tiap kelompok melakukan diskusi dan menyempurnakan Assoziogramm yang telah dibuat. Akhirnya tiap kelompok akan menuliskan karangan mereka tentang Umweltschutz dan mempresentasikannya.
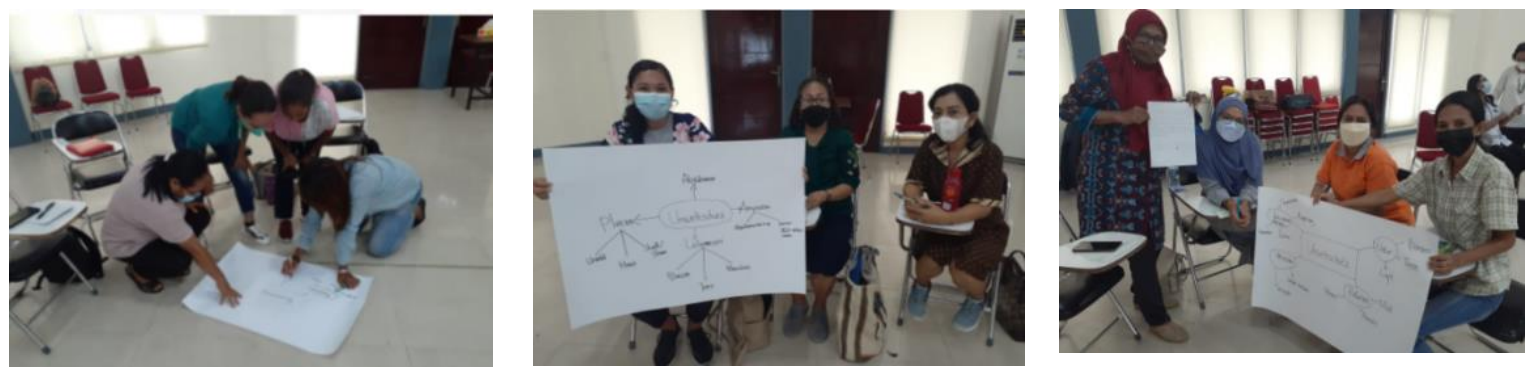

c. Pelatihan dilanjutkan dalam bentuk daring dimana peserta secara individu membuat Assoziogramm tentang Online-Lernen. Selain pengalaman yang telah diperoleh dalam pelatihan, mereka dapat mencari materi yang terkait pada YouTube dan juga link-link lainnya yang terkait dengan bahasa Jerman. Bila mereka mengalami kesulitan, mereka berdiskusi dengan tim PKM melalui Whatsapp.

d. Pada tahap akhir, peserta pelatihan mengirimkan output berupa Assoziogramm dan karangan secara pribadi kepada tim melalui email. 


\section{PEMBAHASAN}

Pelatihan yang merupakan kegiatan Pengabdian Kepada Masyarakat (PKM) ini memberikan penguatan bagi guru dalam mengembangkan kompetensi berbahasanya, terutama untuk meningkatkan kemampuan menulis guru bahasa Jerman pada level B1 dalam mewujudkan guru profesional yang mampu bersaing secara global.

Hasil kegiatan PKM secara garis besar mencakup beberapa komponen sebagai berikut: (a) jumlah peserta, (b) ketercapaian tujuan, (c) materi; dan (d) kemampuan peserta dalam penguasaan materi. Keempat komponen ini merupakan pilar yang membangun keberhasilan kegiatan pengabdian.

Jumlah peserta pelatihan mencapai $90 \%$ dari 20 orang yang telah mendaftar. Target peserta pelatihan seperti direncanakan sebelumnya adalah 20 guru bahasa Jerman. Dalam pelaksanaannya, kegiatan ini diikuti oleh 18 orang peserta. Dengan demikian dapat dikatakan bahwa target peserta tercapai 90\%. Angka tersebut menunjukkan bahwa kegiatan PKM dilihat dari jumlah peserta yang mengikuti dapat dikatakan baik.

Tercapainya tujuan kegiatan. Ketercapaian tujuan kegiatan pelatihan ini secara umum sudah baik. Hal ini terlihat dari hasil kerja peserta baik secara kelompok maupun individu. Dengan demikian dapat disimpulkan bahwa tujuan kegiatan ini dapat tercapai.

Materi yang disiapkan tersampaikan secara keseluruhan. Materi yang telah disiapkan pada kegiatan PKM ini dapat tersampaikan secara menyeluruh yakni (1) materi tentang keterampilan menulis dalam bahasa Jerman, materi tentang Model tes menulis level B1 bahasa Jerman terdiri dari 3 bagian. Bagian 1 berisikan Textfeld für die E-Mail kepada teman, bagian 2 berisikan pendapat terhadap suatu hal (diskusi, komentar, dll), sedangkan bagian 3 berisikan Textfeld für die E-Mail yang resmi (Goethe Institut, 2015). Pada pelatihan ini lebih ditekankan pada bagian 2. Penilaian dalam menulis didasarkan pada koheren, kosakata dan juga Struktur; (2)Materi tentang teknik Assoziogramm;

Kemampuan peserta dalam penguasaan materi. Dari hasil kerja kelompok dan juga individu, tercatat bahwa mereka rata-rata berhasil mengaitkan poin-poin yang dalam Assoziogramm dengan baik dan menulis keterhubungan poin-poin dalam Assoziogrammm itu dengan cukup baik. Hal ini berarti, peserta memiliki pemahaman yang cukup baik dalam menggunakan Assoziogramm untuk menulis.

Secara keseluruhan kegiatan ini dapat dikatakan baik terlihat dari antusias peserta setelah mengikuti kegiatan, dan diharapkan daripeserta bahwa kegiatan ini akan berkelanjutan mengingat sangat penting bagi keterampilan bahasa Jerman guru, khususnya keterampilan menulis.

\section{KESIMPULAN}

Program "Pelatihan Peningkatan Keterampilan Menulis dengan Menggunakan Assoziogramm" bagi guru bahasa Jerman terselenggara dengan baik dan berjalan dengan lancar sesuai dengan rencana kegiatan yang telah disusun. Kegiatan ini mendapat respon baik dari peserta. Hal ini ditandai dengan keseriusan dan antusiasme peserta dalam mengikuti pelatihan sampai selesai, juga dalam menyelesaikan tugas baik secara kelompok maupun individu. Materi yang disajikan juga sesuai dengan kebutuhan guru bahasa Jerman dalam meningkatkan kompetensi menulis mereka.

Diharapkan adanya keberlanjutan pelatihan sejenis mengingat pelatihan ini penting untuk pengembangan kompetensi guru bahasa Jerman karena memberikan kontribusi bagi mereka terutama dalam mempersiapkan tes bahasa Jerman pada level B1. 


\section{DAFTAR PUSTAKA}

Anonim. 2004. Gemeinsamer europäischer Referenzrahmen für Sprachen: Kurzinformationen. (online) http:// https://www.uni-hamburg.de/allgemeinsprachen/ueber-uns/up-ger-u-kurzinfo.pdf. Diakses pada tanggal 8 September 2021

Goethe Institut. 2015. Zertifikat Modelsatz B1. https://bfu.goethe.de/b1_mod/schreiben.php. Diakses pada tanggal 8 September 2021

Hernowo. 2005. Quantum Writing. Bandung: Mizan

Mahmud H. 2017 Upaya Meningkatakan Keterampilan Menulis Dengan Teknik RCG (Reka Cerita Gambar) Pada Siswa Kelas VI SDN Rengkak Kecamatan Kopang, Kabupaten. Lombok Tengah, http://ejournal.mandalanursa.org/index.php/JISIP/article/viewFile/178/169

Rico, Gabrele L. $1984 . \quad W r i t i n g$ the Natural http://www.gabrielerico.com/home/index.php?option=com_frontpage\&Itemi d=1 D

Rusman. 2011. Model-model Pembelajaran Menulis. Bandung: Rajawali Pers

Sabine, Diensel dan Reiman, Monika. 2002. Zertifikat für Indonesische-Deutsch Studenten. Germany: Max Hueber Verlag

Tarcher. J.P. 2007. Clustering for Creativity. Los Angeles. http://www.thelearningweb.net/chaptera12/page430/html.

Wacker, Manfred, dkk. 1996. Fertigkeit Schreiben. Jakarta: Langenscheidt.

Wycoff, Joyce. 2002. Menjadi Superkreatif dengan Pemetaan Pikiran. Bandung: Kaifa. 
